\title{
HUMAN DIMENSION OF THE CHRISTIAN LITURGY
}

\begin{abstract}
Human dimension of the liturgy can be understood only if we are able to grasp the essence of the Christian liturgy, its nature and theological sense and when we realize the criteria which allow us to distinguish "liturgy" from "non-liturgy".

The paper is an attempt to describe a human dimension of the liturgy understood mostly as an anamnesis, a real salvific presence of Christ's Mystery; a real presence resulting from an objective fact that the liturgy is the performing of a priestly function of Christ by Him and the whole Mystical Body, the Church.

The liturgical anamnesis is the acting of Christ as both God and Man. Thus, firstly, a human dimension of the liturgy is directly linked with the hypostatic union of two natures in Christ and results from the human nature of the Saviour. Secondly, the liturgy is the anamnesis of Christ's Mystery for the sanctification and salvation of people. This fact should be viewed as a fundamental historico-salvific sense of the liturgy which is the final stage on earth in the history of salvation. Finally, the Christian liturgy due to a psychosomatic nature of man occurs at the present stage of the history of salvation under the cover of a visible earthly reality.
\end{abstract}

Keywords: liturgy; anamnesis; liturgy and man.

Streszczenie. Ludzki wymiar liturgii chrześcijańskiej. Ludzki wymiar liturgii można właściwie pojąć jedynie wówczas, gdy zrozumie się istotę liturgii chrześcijańskiej, jej naturę i sens teologiczny, oraz gdy uświadomi sobie kryteria pozwalające na odróżnienie „liturgii” od „nie-liturgii”. 
W artykule podjęto próbę opisania ludzkiego wymiaru liturgii rozumianej przede wszystkim jako anamneza, czyli realna obecność zbawcza Misterium Chrystusa; realna obecność wynikająca z obiektywnego faktu, że liturgia jest wykonywaniem kapłańskiej funkcji Chrystusa przez Niego samego i przez całe Jego Mistyczne Ciało, czyli Kościół.

Liturgiczna anamneza to działanie Chrystusa jako Boga i zarazem Człowieka. Tak więc, ludzki wymiar liturgii, po pierwsze, wiąże się bezpośrednio z unią hipostatyczną dwóch natur w Chrystusie i wynika z ludzkiej natury Zbawiciela. Po wtóre, liturgia jest anamnezą Misterium Chrystusa dla uświęcenia i zbawienia ludzi. W tym fakcie należy upatrywać podstawowy sens historiozbawczy liturgii, będącej ostatnim, ziemskim etapem historii zbawienia. I wreszcie, liturgia chrześcijańska z racji psychosomatycznej natury człowieka dokonuje się na obecnym etapie dziejów zbawienia pod osłoną widzialnych, ziemskich rzeczywistości.

Słowa kluczowe: liturgia; anamneza; liturgia i człowiek.

\section{INTRODUCTION}

The title of the paper and the expressed theme seem to be obvious: the Christian liturgy has a human dimension. However, speaking or writing about the liturgy, or conducting it, it is possible to forget somehow that the Christian liturgy has, above all, a divine dimension as it is a salvific action of Jesus Christ. This constitutes the essence and the most profound meaning of the liturgy. People who take part in the liturgy always act in persona Christi, whereas the resurrected and glorious Christ who gives glory to His heavenly Father is the main Liturgist. ${ }^{1}$

Human dimension of the liturgy which is the focus of this paper can be properly understood only if we grasp the essence of the Christian liturgy, its nature and theological sense and if we realize the criteria which allow us to distinguish "liturgy" from "non-liturgy". The latter was defined by the Constitution on the Sacred Liturgy of the Second Vatican Council

${ }^{1}$ In the paper the fragments of the earlier publications of the author have been used: D. Brzeziński, Chrystus wczoraj i dziś, i na wieki. Anamnetyczny wymiar roku liturgicznego, Second Edition Corrected and Enlarged, Toruń 2015; D. Brzeziński, "Liturgia skarbem Kościoła. Historiozbawczy wymiar liturgii chrześcijańskiej,” in: M. Chojnacki, J. Morawa, A. A. Napiórkowski (eds.), O bogactwach Kościoła, Kraków 2014 (Cracoviensis Cogitatio Ecclesialis, vol. 6), pp. 13-25; D. Brzeziński, "Liturgia w kluczu genetyki," Liturgia Sacra 24 (2018) no 1, pp. 17-31. 
Sacrosanctum Concilium as pia exercitia populi christiani ("popular devotions of the Christian people"). ${ }^{2}$ There exists an ontic difference, an ontic chasm, it might be even said, between the liturgy, namely the action of Christ, and "non-liturgy", that is the action of man, such as conducted devotions or prayers initiated by people. ${ }^{3}$

In this paper we will not address the theme of devotions. We will attempt to describe a human dimension of the liturgy understood mostly as an anamnesis, a real salvific presence of Christ's Mystery; a real presence resulting from an objective fact that the liturgy is the performing of a priestly function of Christ by Him and the whole Mystical Body, the Church.

Liturgical anamnesis is the acting of Christ as both God and Man. Thus, firstly, a human dimension of the liturgy is directly linked with the hypostatic union of two natures in Christ and results from the human nature of the Saviour. Secondly, liturgy is the anamnesis of Christ's Mystery for the sanctification and salvation of people. This fact should be viewed as a fundamental historico-salvific sense of liturgy, which is the final stage on earth in the history of salvation. ${ }^{4}$ Finally, the Christian liturgy due to a psychosomatic nature of man occurs at the present stage of the history of salvation under the cover of a visible earthly reality.

\section{LITURGY AS THE ANAMNESIS OF CHRIST'S MYSTERY}

Firstly, the attempt to formulate the definition of the Christian liturgy will be made remembering that the creation of any definition of liturgy due to its divine-human dimension will be always a more or less accurate effort to understand its nature and essence per analogiam. The Christian liturgy being, above all, a salvific action of God and not only

2 See the Constitution on the Sacred Liturgy Sacrosanctum Concilium (SC), 13. Quotations and phrasings from Church documents come from the official website of the Holy See.

3 See D. Brzeziński, “'Liturgia’ i 'nie-liturgia’: w poszukiwaniu kryteriów klasyfikacji," Liturgia Sacra 31 (2008) no 1, pp. 69-82.

${ }^{4}$ See D. Brzeziński, "Liturgia jako ostatni ziemski etap historii zbawienia," Studia Płockie 27 (1999) pp. 37-41. 
an ordinary, laudatory human act cannot be fully and adequately defined as it is a divine-human reality. Various aspects of liturgy can be described but the liturgy as such cannot be precisely defined. ${ }^{5}$

According to the Constitution on the Sacred Liturgy of the Second Vatican Council Sacrosanctum Concilium and the Catechism of the Catholic Church which repeats the key statements of the Constitution concerning an attempt to provide a theological description of the Christian liturgy, the liturgy is the work of Christ the Head and His Church:

the liturgy is considered as an exercise of the priestly office of Jesus Christ. In the liturgy the sanctification of the man is signified by signs perceptible to the senses, and is effected in a way which corresponds with each of these signs; in the liturgy the whole public worship is performed by the Mystical Body of Jesus Christ, that is, by the Head and His members. ${ }^{6}$

Indicating the essence of the Christian liturgy, both the Constitution and the Catechism of the Catholic Church remind the faithful that the Resurrected Christ imparting the Holy Spirit to the Apostles entrusted them and their successors with the power of sanctifying and saving. This "apostolic succession" has been handed down for twenty centuries in the sacrament of ordination. Thanks to sacramental priesthood, which was strongly emphasized by, among others Pius XII (+1958) in his Encyclical on the Sacred Liturgy Mediator Dei, ${ }^{7}$ it is possible to continue to conduct the liturgy, in which Christ as well as bishops and presbyters acting in persona Christi still actualize the same work which took place during the Last Supper, on the Cross and in the morning of the Resurrection. Thus, the earthly liturgy becomes the next stage of the history of salvation. After the period of the Old Testament (when the people awaited the Savior) and after the fullness of time in the New Testament (when Christ reconciled us with His Father) our salvation and sanctification take place in the liturgy of the Church, which, in turn, is the continuation of the time of Christ. It happens not only through a simple and obvious fact

${ }^{5}$ See D. Brzeziński, "W poszukiwaniu teologicznego sensu liturgii. Refleksje na 2000-lecie chrześcijaństwa," Studia Płockie 28 (2000) p. 37.

6 SC 7; cf. The Catechism of the Catholic Church (CCC), 1070.

7 See. Pius XII, Encyclical on the Sacred Liturgy Mediator Dei, 1-3. 
of the sequence of time. "The line of continuation" called in this way by S. Marsili ( $\dagger 1983$ ) combining the time of the Church with the time of Christ is formed by the sacred liturgy. ${ }^{8}$

The anamnetic dimension of the Christian liturgy results from the fact that Christ Himself with His Mystical Body performs the liturgy. The concept of "anamnesis" has become a dominant feature of the liturgy in the modern theology of liturgy. Without understanding the essence of anamnesis, it is impossible to grasp the essence of the Christian liturgy. Without anamnesis, the liturgy is not simply the liturgy. ${ }^{9}$

Liturgical anamnesis is an objective remembrance and actualization hic et nunc of the Paschal Mystery of Christ. This is an objective reminder of the past, but also anticipation of the future, the heavenly liturgy; something impossible - and nearly incomprehensible - for a human being, but possible for God. Salvific events, which we celebrate every day, especially in the Eucharist, although they took place only once in specific temporal and spatial circumstances and they were never repeated and will not be repeated historically, thanks to the presence and action of the Holy Spirit, "the Church's living Memory"10 and "the Artisan of God's masterpieces", which are the sacraments of the New Covenant, ${ }^{11}$ each time when we celebrate them in the liturgy become present today in a sacramental manner: in mysterio, and not only in consequences or salvific fruits.

The anamnesis of the Mystery of Christ in the liturgy excludes any narrowing of it to a purely psychological or mental, that is subjective recollection of salvific events, both past and future. Liturgical celebrations have the character of independent and objective remembrance, together

${ }^{8}$ Cf SC 5-8; CCC 1077-1090; S. Marsili, "La liturgia - momento storico della salvezza," in: S. Marsili (ed.), Anàmnesis. Introduzione storico-teologica alla liturgia, vol. 1: La liturgia - momento nella storia della salvezza, Casale Monferrato 1988 (ristampa), pp. 91-92.

9 To understand the sense of anamnesis in the liturgy, it is necessary to refer to the biblical meaning of anamnesis: "zikkaron" in the Old Testament and "anámnesis" in the New Testament. In all biblical literature, neither "zikkaron" nor "anamnesis" are ever understood as mere, subjective reminiscence of facts from the past; see more on this subject D. Brzeziński, Chrystus wczoraj i dziś, i na wieki, pp. 119-146.

${ }^{10}$ CCC 1099.

11 CCC 1091. 
with its saving kairós, in which Christ is present and works "here" and "now". It was, among others, O. Casel $(+1948)$, the brilliant creator of Mysterientheologie who "liberated" liturgical hodie from the possibility of erroneous understanding of liturgy as an intellectual and mental act of remembrance. This category of liturgical hodie ("today"), rediscovered by Casel from abundant biblical and early Christian sources, is the foundation for understanding the anamnetic dimension of the Christian liturgy.

Liturgical anamnesis differs significantly from the anamnesis understood as a subjective "recollection" in Platonism and neo-Platonism"12 and from the conception of the anamnesis of St. Augustine $(\dagger 430)$ with its timeless eternal truths, comprehended thanks to enlightenment by God. ${ }^{13}$ It is also different from how anamnesis was conceived by modern nativist theory related to Augustinianism. ${ }^{14}$

Anamnesis in the liturgy - even though there are many analogies and similarities here - is also something different from the anamnesis proposed as a method of catechesis. Without negating the real and effective salvific presence of Christ in catechesis, it is difficult to grant it

12 According to Plato ( $† 347$ B.C.), anamnesis is based on discovering by human being in his memory the knowledge of ideas that he acquired during previous stages of existence. This discovered knowledge is therefore innate. "Placed" in an immortal soul, it concerns the truths about universal ideas, values and beings as beings. Concrete material beings are never its subject. Sensory contact with the visible world is an opportunity and occasion to remember and realize ("recall") this knowledge already possessed and acquired in a previous incarnation. Along with recalling the past, the actualization of seeing the essence of the matter as "here" and "now" takes place; see D. Brzeziński, Chrystus wczoraj i dziś, i na wieki, pp. 33-47.

${ }^{13}$ Augustine's epistemological concept should be considered as an "anamnetic concept," in which the Platonic and Neoplatonic anamnesis ("recollection") was purified of reincarnation theory and enriched with an element of Divine enlightenment or illumination, see ibid., pp. 48-54.

14 A slightly different approach to anamnesis was offered by modern nativist theory, proposed by, among others, R. Descartes ( $\uparrow 1650)$ and G. W. Leibniz (†1716). According to them, God, while creating human beings, equipped them with the knowledge of basic religious, philosophical and moral truths, i.e. innate ideas. Representatives of nativism believe that the basis of human cognition is richer than the data obtained through the experience of reality, as it also includes information inscribed in human nature: ideas or some other forms of knowledge. The human mind possesses the ability to find these ideas, that is, "to recall them thanks to God's 'natural light"; see, ibid., pp. 55-60. 
a sacramental character. It is also not easy - even after the application of the definition of liturgy to the reality of catechesis - to perceive it as a celebration of the salvific events in mysterio. ${ }^{15}$

The anamnesis in the Christian liturgy also differs in essence from the "anamnesis" in the ancient mystery cults, although in this case we may observe a formal analogy (solely and exclusively formal) between the way of understanding the anamnesis in the known mystery cults and the anamnesis of the Mystery of Christ which takes place in the Christian liturgy, the subject which was studied and aptly described by, among others, O. Casel. ${ }^{16}$

It seems that the aforementioned ways of understanding anamnesis, especially its interpretation in philosophy, may greatly influence its distorted vision in the liturgy. There is a danger of reducing the liturgical anamnesis to recollection and making the Mystery of Paschal Christ present only in some psychological manner, that is only in our memory and consciousness. However, the essence of the liturgy and the foundation of its existence is not the subjective recollection of salvific events but their real presence in mysteries conducted by the whole Church, namely by Christ - the Head and the members of His Mystical Body.

The identification of a significant and fundamental difference between the non-cultic, and consequently also the non-liturgical understanding of anamnesis on the one hand, and its understanding in the liturgy on the other, allows for a clear realization that the liturgical anamnesis is an objective reality existing independently of man as a cognizing or acting subject. Furthermore, without such anamnesis, the Christian liturgy, as we have already emphasized, could not exist.

\section{LITURGY AS THE ANAMNESIS OF THE MYSTERY OF CHRIST AS GOD-MAN}

The eternal God, from the moment when "the Word became flesh and dwelt among us" (cf. John 1:14), directly entered into the history of

\footnotetext{
15 See ibid., pp. 61-69.

16 See ibid., pp. 73-112.
} 
the world which He created and joined with time and space. Together with the Incarnation of the Son of God the consecratio mundi was also accomplished: the world became the sacrament of redemption, the history of the universe and man became a holy history and time gained a salvific dimension. "The fullness of time" came into existence and a new, salvific kairós began.

The liturgy is nothing else but this kairós, or rather a series of kairoi. In this sense, it is the "carrier" of salvation, both in the objective sense and in the subjective dimension, regarding every human person called by God to salvation. ${ }^{17}$

The Christian liturgy is a consequence of the Incarnation, the culmination of which was the Resurrection and Ascension; it is the anamnesis of the presence of the Son of God on earth and the entry of God into human history and human time (as we can observe with full awareness of the lack of terminological and theological precision in relation to such concepts as "human time" or "human history").

Just as the entry of God into time and human history changed and deified them, so also in the Church's "aeon", thanks to the liturgy and through the liturgy, the "secular history" becomes more and more complete and thus is transformed into the "sacred history". The celebration of the liturgy "until the end of the world" leads to the process of "Christification" of history, permeated with the presence of Christ and the presence of His Paschal Mystery. ${ }^{18}$

Liturgical time is marked by the present ("right now") of God's salvation and the salvific presence of God which is being realized "right

${ }_{17}$ See ibid., pp. 273-309; "Liturgiczny kairos czasem eschatycznej nadziei i jej wypełnienia," in: K. Filipowicz (ed.), "Chlubimy się nadzieją chwały Bożej” (Rz 5, 2). Ksiegga dedykowana ks. prof. dr. hab. Janowi Decykowi, Warszawa 2016, pp. 117-129.

${ }_{18}$ The blending in history of all transcendent values is emphasized by the Orthodox theology, according to which all history - open to receiving the Divine - is one great liturgy. Thus, the ordinary sense of chronological time disappears. According to this approach, such time as an autonomous value does not exist. Every form of time is understood as kairòs, in which God comes into the world and man is "drawn" by Christ into divine eternity. The sacred time of celebrating the liturgy is not some other type of history, but an intensification of salvific values in the community of the participants of the liturgy; see J. Bellavista, "La celebración del tiempo en las Iglesias orientales," Phase 19 (1979) pp. 367-375. 
now". The eternity and the timelessness of God thanks to the Incarnation of the Son of God is the entry of the "Divine now" into the course of created time. The Paschal Mystery of Christ crushed the structure of the worldly chronology, which does not count any more or loses its significance and gradually disappears. The latter, more moderate approach accepts the existence of chronological history which disappears, transforms itself and deifies, leading to the final unity with the Resurrected Christ. ${ }^{19}$

Although posed hypotheses try to explain rationally and empirically the problem of the contact of time with the liturgy, it should be emphasized that in these efforts we always face God's mystery. There is no doubt, however, that in the liturgy a meeting in mysterio of human time with God's eternity takes place. There is spaciotemporal opening to God's infinity. The liturgy, thanks to its anamnetic dimension, becomes a place where time intersects with eternity.

The thesis that the liturgy of the Church is a consequence and continuation of the Incarnation of the Word of God, and the presence and actualization (re-praesentatio) of "here" and "now" of the salvific work of Christ and the Person of the Savior has become a sort of "axiom" of the theology of the liturgy by J. Pinsk (†1957). According to this German scholar and one of the precursors of the liturgical movement, the key to understand the essence of the liturgy lies in the fact of the Incarnation. ${ }^{20}$

By coming into direct contact with matter, the Son of God, through the liturgy, makes it possible to sanctify the world, consecratio mundi. This expression, borrowed from Maria-Laach, became the keynote of Pinsk's entire teaching. The Incarnation is a cosmic event that brought salvation

19 Cf. J. Nowak, "Ponadczasowy charakter liturgii," in: S. Koperek, R. Tyrała (eds.), Ante Deum stantes, Kraków 2002 (Pontificia Academia Theologica Cracoviensis. Facultas Theologica, Studia, vol. 7), pp. 462-463.

20 See J. Stefański, “Wprowadzenie. Słowo o autorze. Słowo o książce”, in: J. Pinsk, Świat i sakramenty, Kraków 1997 (Vetera et nova. Biblioteka przekładu klasyków liturgiki Instytutu Liturgicznego w Krakowie, ed. S. Koperek, vol. 4), pp. 29-59. 99-100; J. Stefański, "Zbawczy i kosmiczny wymiar aktu liturgicznego. Pojęcie liturgii według Jana Pinska," Studia Theologica Varsaviensia 20(1982) no 1, pp. 7-46; J. Stefański, "Johannes Pinsk - liturgista oryginalny i tradycyjny," in: A. Krzystek (ed.), Johannes Pinsk prekursor posoborowej odnowy liturgicznej, Szczecin 2008 (Wydziat Teologiczny Uniwersytetu Szczecińskiego. Studia i rozprawy, vol. 20), pp. 79-92. 
to man and the world (das Heil). The carrier of this process is Pneuma Christi, the Spirit of Jesus Christ, who, together with the human body, creates a supernatural unity in Jesus Christ. Pneuma Christi is a union between His Deity and Humanity; a union which, after the Resurrection and Ascension, was given to the community of believers as the Mystical Body of Christ. This community of the Mystical Body of Christ is a gathering in Pneumate Christi.

The consecration of the world is available to every human being thanks to the material, external signs which are used by the liturgy. This "accessibility" and "tangibility" of liturgical actions do not weaken in any way the value of their objectivity. They are Christ's personal act for people.

Pinsk believes that the liturgy in a broader sense covers the entire universum, from the moment of the world's creation to the second coming of Christ. Each liturgical act has a cosmic character. Through the Incarnation Christ became das Heil for the world. He sanctifies it permanently and consecrates, granting it the dimension of "sacramentality" through redemption and sanctification, being Himself the Sacrament of God.

The "sacramental dimension of man" and "the sacramental structure of the world of things", including the sacramental nature of space and time: "sacred space" and "sacred time" are inscribed in the sacramental character of the created and redeemed world. Through the historical fact of the Incarnation and the action of the Church in history, time is considered as "sacramental time." This also applies to space. We do not sanctify time and space through our good works, but the time and space in which Christ's life unfolds make us holy.

Thus, the ties of the eternal Logos with time and space, as Pinsk emphasized, result from the fact that the Logos was associated with the spiritual and bodily human nature. This denotes that the eternal, timeless God enters through the successive activities of the Logos carried out in the body into time and thus grants it, within the structure of what is created, a new quality based on being - the quality of holiness. In fact, sacred time begins with the incarnation of the Son of God. ${ }^{21}$

${ }^{21}$ For more on this topic, see J. Pinsk, Die Sacramentale Welt, Freiburg 1938. 


\section{LITURGY AS THE ANAMNESIS OF THE MYSTERY OF CHRIST FOR THE SANCTIFICATION AND SALVATION OF PEOPLE}

Etymologically, the term 'liturgy' denotes a 'public act' or an 'action for people. In ancient Greece, public service was called the liturgy. "Liturgies", viewed from this perspective, were a characteristic feature of the socio-political life of Hellenic democracies, but also of temple service in ancient mystery religions. Obviously, we find both the secular and religious meaning of the term 'liturgy' in the Septuagint and in the New Testament. And in this sense, the term 'liturgy', in all its theological and pastoral richness, is used by the Church. It denotes a unique, salvific action for the glory of God and for the spiritual benefit of people. ${ }^{22}$

The Christian liturgy is an encounter between the Mystery of God and human life. God enters human existence "here and now", and people participate in God's life. In this meeting the divine dimension of the liturgy and its human dimension permeate each other. ${ }^{23}$

Thanks to the liturgy and through liturgy, sanctification and salvation take place in the current spacetime. Thanks to the liturgy, we do not have to, colloquially speaking, "regret" or "worry" that we do not live in the time of Christ, as through its anamnetic dimension all salvific events from two thousand years ago are present "here" and "now" each time we celebrate the sacred liturgy of the Church. This presence, making real the past hic et nunc, anticipates, at the same time, an eschatic future, namely the Heavenly Jerusalem. ${ }^{24}$

22 See S. Marsili, La liturgia, pp. 33-45; B. Nadolski, Leksykon liturgii, Poznań 2006, pp. 745-748.

${ }^{23}$ It is worth noting that the so-called Roman liturgical school associated mostly with the Pontifical Liturgical Institute of St. Anselm in Rome perceives the liturgy in the key mysterium - actio - vita. One of its leading representatives A. M. Triacca (+2002) often used to say that it is primarily in the liturgy that the Mystery of God reaches symbiosis with human life, and the liturgy is nothing else but the "Mystery celebrated for life"; see Nuovo dizionario di liturgia, (eds.) D. Sartore, A. M. Triacca, Cinisello Balsamo 1988, p. XXVI; H. J. Sobeczko, "Mysterium - actio - vita. Teologia liturgiczna szkoły rzymskiej," in: K. Porosło (ed.), Teologia żyjąca w liturgii. Materiały z II Rekolekcji Liturgicznych "Mysterium fascinans" (4-6 września 2009), Kraków 2010, pp. 13-24.

${ }^{24}$ See D. Brzeziński, Liturgia skarbem Kościoła, pp. 13-25. 
"Just as Christ was sent by the Father," as we read in the Constitution on the Sacred Liturgy,

so also He sent the apostles, filled with the Holy Spirit. This He did that, by preaching the gospel to every creature, they might proclaim that the Son of God, by His death and resurrection, had freed us from the power of Satan and from death, and brought us into the kingdom of His Father. His purpose also was that they might accomplish the work of salvation which they had proclaimed, by means of sacrifice and sacraments, around which the entire liturgical life revolves. ${ }^{25}$

The Conciliar Constitution extremely aptly expresses the essence and the deepest historico-salvific sense of the sacred liturgy as well as the whole mission of Christ's Church: the liturgy is celebrated for the sanctification and salvation of people. ${ }^{26}$ The effectiveness of the conducted mysteries, which is possible and real thanks to the anamnetic dimension of the liturgy, leads to the sanctification of its participants. Odo Casel calls this sanctification "deification" (Vergötlichung), thus referring to the theology of the Greek Fathers. ${ }^{27}$

Thus, the liturgy is the time and space of real and objective sanctification and salvation; salvation brought by Christ for us. The liturgy of the Church is the privileged locus redemptionis; it is a time and space of grace, where opus redemptionis Christi is present in sacramento.

It is clear that an objective actualization of this Mystery in the individual life of each person must take place; in other words, there must be a subjective acceptance of the objective salvation offered by Christ and His Church.

Thus, at every possible opportunity, preaching, catechesis, and broadly understood pastoral care should constantly made the faithful aware of the fact that in the liturgy a real and effective meeting of man and Christ takes place in the individual mysteries of His Paschal Mystery; the meeting in perpetual mysteries in the sanctifying liturgy of today. This

${ }^{25} S C 6$.

26 See SC 7.

${ }^{27}$ Cf W. J. Pałęcki, “Odo Casel. Nauka o misteriach chrześcijańskich,” in: Leksykon wielkich teologów XX/XXI wieku, vol. 3, eds. J. Majewski, J. Makowski, Warszawa 2006, p. 53. 
encounter, as we have already emphasized, does not consist in a thought awareness of past salvific events and volitional and emotional identification with them, or a certain external rite "added" to the Eucharist on a given day. It is based on the anametic presence and salvific effectiveness of the Lord's Mystery. ${ }^{28}$

It is important to emphasize once again that the Christian liturgy not only recalls the events through which our salvation took place, but also makes them present and ensures continuity between the historical salvific event and its celebration. Apparently, we cannot speak here of any repetition of the historical act of the death or resurrection of Christ, or of making Him present in the historical reality, as it is contrary to the realism of the Incarnation and the human nature of Christ which is subjected to the laws of time. ${ }^{29}$

\section{LITURGY AS THE ANAMNESIS OF THE MYSTERY OF CHRIST TAKING PLACE UNDER THE COVER OF VISIBLE SIGNS}

The Paschal Mystery must be effectively and noticeably present in the Church so that the redemption brought by Christ could be realized in every person through his personal participation in the Paschal Mystery. The liturgy of the Church, focused around signs deriving their supernatural effectiveness from the historical deeds of Christ is precisely this salvific and effective actualization of the Paschal Mystery in time and space. ${ }^{30}$

28 The real salvific power of the liturgy is probably most easily visible for the faithful in the administering of the sacrament of baptism, the sacrament of penance and reconciliation, the sacrament of the anointing of the sick and the celebration of the Eucharist. On the other hand, the celebration of the other sacraments, not to mention the celebration of the liturgy of the hours, frequently seems to remain outside the realm of salvific action in the minds of the faithful.

${ }^{29}$ Casel's theology of mystery teaches us about the timeless and sacramental presence, and thus the essential presence ("in substance") of the Paschal Mystery of Christ, see D. Brzeziński, Chrystus wczoraj i dziś, i na wieki..., p. 218.

${ }^{30}$ Cf. W. Hryniewicz, "Liturgia a Misterium Paschalne Chrystusa," in: F. Blachnicki, W. Schenk, R. Zielasko (eds.), Wprowadzenie do liturgii, Poznań-Warszawa-Lublin 1967, p. 89. 
B. Nadolski (†2018) described this as a relation between imitating Christ's actions (a mimetic function) and making His salvific actions present. However, this presence can only take place in the power of the Holy Spirit and thanks to the real presence of Christ in the liturgy. ${ }^{31}$ This is what "the exercise of the priestly office of Jesus Christ" in the liturgy means. ${ }^{32}$

Thus, the liturgy is the anàmnesis and mimesis of the Paschal Mystery of Christ. Just like two thousand years ago during His earthly life, Christ, God-Man, the High and Eternal Priest offers Himself in sacrifice to God the Father under the cover of signs every time the liturgy is celebrated. ${ }^{33}$

This perspective helps us to interpret the statements of the Constitution Sacrosanctum Concilium about the real, supernatural and, at the same time, visible presence of Christ in the liturgy. Christ "is present in the sacrifice of the Mass, not only in the person of His minister, 'the same now offering, through the ministry of priests, who formerly offered himself on the cross', but especially under the Eucharistic species. By His power He is present in the sacraments, so that when a man baptizes it is really Christ Himself who baptizes. He is present in His word, since it is He Himself who speaks when the holy scriptures are read in the Church. He is present, lastly, when the Church prays and sings, for He promised: 'Where two or three are gathered together in my name, there am I in the midst of them' (Matt. 18:20)".34

31 See B. Nadolski, Wprowadzenie do liturgii, Kraków 2004 (Myśl Teologiczna, eds. A. Baron, H. Pietras, vol. 42), p. 23.

32 SC 7.

${ }^{33}$ Cf. CCC 1088.

${ }^{34}$ SC 7; see S. Marsili, La liturgia, pp. 92-96. Western theology teaches that the priest acts "in persona Christi" during the liturgy. All the power and dignity of the priest originates from his participation in the priesthood of Christ. The priest makes present the person of Christ who is the first Liturgist. By analogy to the seven sacramental signs, the priest - is the "sacrament" of Christ, the High Priest. Sometimes, it is also said that he is a "figure" or an "image of the Lord" or an "icon of Christ" the Prophet, Priest and Shepherd. The celebration of the liturgy should always take place with the awareness that Christ is the first Liturgist to celebrate holy mysteries. The priest, however, should "identify with the person of the Lord by speaking His words and repeating His gestures". Only bishops and presbyters act "in persona Christi Capitis". The lay faithful, who have been 
Visible signs of the liturgy include both unchanging and changing elements. Words, gestures, symbols and signs as well as natural elements (such as bread and wine, which become the Eucharist by the will of Christ and by the power of His words) present in the liturgy by God's establishment belong to constant and non-negotiable realities which do not undergo any changes.

Apart from this divine element (though in this case falling under human senses), there are symbols and signs, words and gestures, objects and natural elements introduced into the liturgy by man and subject to inevitable evolution and legitimate liturgical renewal, in accordance with the principle semper liturgy reformanda est, reformanda in its human layer. They can be compared to the frame of a precious painting. They are like a frame of a masterpiece which changes in historical periods thanks to a hopefully better understanding of what comes from God Himself. ${ }^{35}$

baptized and confirmed, act "in persona Ecclesiae" as the "ministri Corporis Christi"; see D. Brzeziński, "Sztuka sprawowania i przewodniczenia Eucharystii," in: eds. J. Kochański, B. D. Kwiatkowski, M. Milewski, Eucharystia w życiu Kościoła. Materiały z „Płockich Dni Pastoralnych" 30-31 marca 2005 r., Płock 2005, pp. 36-39; D. Brzezinski, “Ars celebrandi Eucharystii jako mistagogia liturgiczna," Studia liturgiczne 14 (2018) pp. 30-33.

${ }_{35}$ Cf. SC 21; A. Läpple, Eucharystia. Ustanowienie, historia, uczestnictwo, Kraków 1997, pp. 5-35. At this point, it is important to signal the conceptual chaos existing in the theological-liturgical and liturgical-pastoral terminology, and to emphasize the abuse of the term "symbol" in relation to liturgical realities, including primarily liturgical signs. The term symbolon originally referred to an object broken into two parts, the adjustment of which (symballein - "matching", "putting together") leads to the identification of two people or their proxies. In modern humanities, a specific relationship between the signifer (signifiant), which is a form, and the signified (signifié) a mental concept, is used where the signified may be ambiguous, based on association, and not on Aristotelian logical principles. The symbol creates a semantic field between the signifier and signified. See A. Szyjewski, Etnologia religii, Kraków 2008, p. 75. In Lexikon der Religionen edited by $\mathrm{H}$. Waldenfels the symbol is defined in a similar vein. A symbol, when it comes to form, should be classified as a sign, because it denotes something, and therefore it does not exist only for itself, but indicates something else. This feature of the symbol, namely referring to something else, combines the level of sensory presentation with a spiritual meaning. See P. Parusel, Symbol, in: H. Waldenfels (ed.), Leksykon religii. Zjawiska - dzieje - idee, Warszawa 1997, p. 446. In modern theology of liturgy, the term "symbol" has a very similar meaning. In The Lexicon of the Liturgy by B. Nadolski, published in Poland, the symbol is defined, among others, as a special category of sign. Not every sign is a symbol, although every symbol is a sign. A sign can be a word, image, symbol, gesture, attitude, 
Each liturgical assembly, Christ as the Head and the members of the Church, is the people of God, a holy convocation, a hierarchical community, a community of believers celebrating the Mystery of Christ. The human elements of this celebration require order and harmony. What is the most important is the theological-dogmatic and theological-liturgical order, but also formal correctness, namely, celebratory and organizational order; dignity and beauty, inscribed in the essence of the liturgy; beauty, which is much more than just aesthetics. ${ }^{36}$

\section{CONCLUSION}

To conclude, it should be added that the obvious consequence of the human dimension of the liturgy, especially taking into consideration this last aspect discussed in the text (but not only), is the need to place the liturgy in the reality of law. The liturgy demands legislation because as a salvific, public, social, harmonious, hierarchical and ordered action, it cannot be subject to the norms arising both from Divine Revelation and the human decisions which are the reflection on the Revelation.

All those who conduct the liturgy in any part of the world are always obliged to obey the sacred and the ensuing principles established by the rightful ecclesiastical authority.

object, person, figure, color, tone or letter. The sign plays the role of an external, noticeable action aimed at communicating something. "The sign indicates the reality, whereas the symbol is part of the signified reality. The reality signified by signs and symbols is very broad. Hermeneutics of religion, which interprets symbols in religion (including their understanding and functions in the liturgy), emphasizes the role of the symbol in the relationship between a human being and the sacred: symbols are a hierophany of this relationship and bond. Just like the whole liturgy, each sign and symbol has four basic dimensions: a) commemorative, recalling the past (signum rememorativum); b) representing the mystery (signum demonstrativum); c) initiating fullness and anticipating the future (signum eschatologicum - prognosticum); d) conferring certain responsibilities (a dimension resulting from the other three; signum obligativum); see B. Nadolski, Leksykon..., pp. 1484-1490; K. Porosło, "Przez rzeczy widzialne do niewidzialnych - symbol właściwym językiem liturgii,” in: K. Porosło (ed.), Teologia żyjąca w liturgii..., pp. 86-109.

36 See P. Marini, Liturgia e bellezza. Nobilis pulchritudo. Memoria di una esperienza vissuta nelle celebrazioni liturgiche del Santo Padre, Città del Vaticano 2005, pp. 73-131. 
"Regulation of the sacred liturgy," reminds the Constitution on the Liturgy,

depends solely on the authority of the Church, that is, on the Apostolic See and, as laws may determine, on the bishop. In virtue of power conceded by the law, the regulation of the liturgy within certain defined limits belongs also to various kinds of competent territorial bodies of bishops legitimately established. Therefore no other person, even if he be a priest, may add, remove, or change anything in the liturgy on his own authority. ${ }^{37}$

Liturgical law is at the service of salvific events. After all, the liturgy is the final earthly stage of salvation history and the anticipation of the heavenly liturgy; it is the Mystery celebrated for the glory of God and for the benefit of people in the perspective of their eternal life. Liturgical and legal norms, which order the liturgy, above all, protect the purity of the celebrated faith and guarantee the doctrinal and liturgical correctness of celebrated mysteries. Most of all, they guard the Divine but also the human dimension of the Christian liturgy.

\section{BIBLIOGRAPHY}

Bellavista J., "La celebración del tiempo en las Iglesias orientales," Phase 19 (1979), pp. 367-375.

Brzeziński D., "Ars celebrandi Eucharystii jako mistagogia liturgiczna," Studia liturgiczne 14 (2018), pp. 21-35.

Brzeziński D., Chrystus wczoraj i dziś, i na wieki. Anamnetyczny wymiar roku liturgicznego, Second Edition Corrected and Enlarged, Torun 2015.

Brzeziński D., "Liturgia' i 'nie-liturgia’: w poszukiwaniu kryteriów klasyfikacji," Liturgia Sacra 31 (2008) no 1, pp. 69-82.

Brzeziński D., "Liturgia jako ostatni ziemski etap historii zbawienia," Studia Płockie 27 (1999), pp. 37-41.

Brzeziński D., "Liturgia skarbem Kościoła. Historiozbawczy wymiar liturgii chrześcijańskiej," in: M. Chojnacki, J. Morawa, A. A. Napiórkowski (eds.), O bogactwach Kościoła, Kraków 2014 (Cracoviensis Cogitatio Ecclesialis, vol. 6), pp. 13-25.

37 SC 22; cf. S. Czerwik, "Liturgia - działanie Boskie i ludzkie. Posłuszeństwo wobec sacrum i osobista twórczość przewodniczącego celebracji," Znak 546 (2000) no 11, pp. $78-79$. 
Brzeziński D., "Liturgia w kluczu genetyki," Liturgia Sacra 24 (2018) no 1, pp. 17-31. Brzeziński D., "Liturgiczny kairos czasem eschatycznej nadziei i jej wypełnienia," in: K. Filipowicz (ed.), 'Chlubimy się nadzieją chwały Bożej’ (Rz 5, 2). Księga dedykowana ks. prof. dr. hab. Janowi Decykowi, Warszawa 2016, pp. 117-129.

Brzeziński D., "Sztuka sprawowania i przewodniczenia Eucharystii," in: eds. J. Kochański, B. D. Kwiatkowski, M. Milewski, Eucharystia w życiu Kościoła. Materiały z "Płockich Dni Pastoralnych" 30-31 marca 2005 r., Płock 2005, pp. 33-53.

Brzeziński D., "W poszukiwaniu teologicznego sensu liturgii. Refleksje na 2000-lecie chrześcijaństwa," Studia Płockie 28 (2000), pp. 37-48.

Czerwik S., "Liturgia - działanie Boskie i ludzkie. Posłuszeństwo wobec sacrum i osobista 'twórczość' przewodniczącego celebracji," Znak 546 (2000) no 11, pp. 76-92.

Hryniewicz W., "Liturgia a Misterium Paschalne Chrystusa," in: F. Blachnicki, W. Schenk, R. Zielasko (eds.), Wprowadzenie do liturgii, Poznań-Warszawa-Lublin 1967, pp. 75-98.

Läpple A., Eucharystia. Ustanowienie, historia, uczestnictwo, Kraków 1997.

Marini P., Liturgia e bellezza. Nobilis pulchritudo. Memoria di una esperienza vissuta nelle celebrazioni liturgiche del Santo Padre, Città del Vaticano 2005.

Marsili S., "La liturgia - momento storico della salvezza," in: S. Marsili (ed.), Anàmnesis. Introduzione storico-teologica alla liturgia, vol. 1: La liturgia - momento nella storia della salvezza, Casale Monferrato 1988 (ristampa), pp. 31-156.

Nadolski B., Leksykon liturgii, Poznań 2006.

Nadolski B., Wprowadzenie do liturgii, Kraków 2004 (Myśl Teologiczna, eds. A. Baron, H. Pietras, vol. 42).

Nowak J., "Ponadczasowy charakter liturgii," in: S. Koperek, R. Tyrała (eds.), Ante Deum stantes, Kraków 2002 (Pontificia Academia Theologica Cracoviensis. Facultas Theologica, Studia, vol. 7), pp. 455-464.

Nuovo dizionario di liturgia, eds. D. Sartore, A. M. Triacca, Cinisello Balsamo 1988.

Pałęcki W. J., "Odo Casel. Nauka o misteriach chrześcijańskich," in: Leksykon wielkich teologów XX/XXI wieku, vol. 3. eds. J. Majewski, J. Makowski, Warszawa 2006, pp. 49-61.

Parusel P., “Symbol”, in: ed. H. Waldenfels, Leksykon religii. Zjawiska - dzieje - idee, Warszawa 1997, p. 446.

Pinsk J., Die Sacramentale Welt, Freiburg 1938.

Porosło K., "Przez rzeczy widzialne do niewidzialnych - symbol właściwym językiem liturgii,” w: K. Porosło (ed.), Teologia żyjąca w liturgii. Materiały z II Rekolekcji Liturgicznych „Mysterium fascinans” (4-6 września 2009 r.), Kraków 2010, pp. 86-109.

Sobeczko H. J., “Mysterium - actio - vita. Teologia liturgiczna szkoły rzymskiej,” in: K. Porosło (ed.), Teologia żyjąca w liturgii. Materiały z II Rekolekcji Liturgicznych „Mysterium fascinans” (4-6 września 2009 r.), Kraków 2010, pp. 13-24.

Stefański J., "Johannes Pinsk - liturgista oryginalny i tradycyjny," in: A. Krzystek (ed.), Johannes Pinsk prekursor posoborowej odnowy liturgicznej, Szczecin 2008 (Wydziat Teologiczny Uniwersytetu Szczecinskiego. Studia i rozprawy, vol. 20), pp. 79-92. 
Stefański J., "Wprowadzenie. Słowo o autorze. Słowo o książce”, in: J. Pinsk, Świat i sakramenty, Kraków 1997 (Vetera et nova. Biblioteka przekładu klasyków liturgiki Instytutu Liturgicznego w Krakowie, ed. S. Koperek, vol. 4), pp. 13-104.

Stefański J., "Zbawczy i kosmiczny wymiar aktu liturgicznego. Pojęcie liturgii według Jana Pinska," Studia Theologica Varsaviensia 20 (1982) no 1, pp. 7-46.

Szyjewski A., Etnologia religii, Kraków 2008. 